\title{
Persons with Substance Abuse Disorders and Other Addictions: Coping with the COVID-19 Pandemic
}

\author{
Justo R. Fabelo-Roche MS PhD, Serguei Iglesias-Moré RN MS, Ana M. Gómez-García MD MS
}

\begin{abstract}
Cuba implemented policies mandating social distancing on March 11, 2020 , which were still in place at the time of this study. During such periods of isolation, people with psychoactive substance-related disorders and other addictions may be tempted to reduce tension, stress, uncertainty and possible distress by increasing the use of substances or practices they have abused. This can mean relapses and setbacks for patients undergoing treatment. A multidisciplinary team of health professionals specializing in addiction at the Center for Academic Development in Drug Addiction, in Havana, Cuba, cares for people with these disorders and followed their evolution during the initial period of COVID-19 social isolation.
\end{abstract}

With the aim of characterizing strategies employed by patients undergoing treatment for substance abuse and addictions, we conducted a qualitative study from April 2020 through May 2020, using a convenience sample of 37 patients (all students) who had been progressing towards recovery from addictive behaviors when face-to-face encounters were suspended due to COVID-19 restrictions. Contact was maintained through information and communication technologies. The research used telepsychology and focused on understanding patient life experiences. Patients were interviewed using a semi-structured survey, which was then transcribed and coded thematically using a grounded-theory approach.

\section{INTRODUCTION}

In 2012, researchers at the Medical University of Havana's $(\mathrm{UCMH})$ Center for Academic Development in Drug Addiction (CEDRO) undertook a research project entitled "Implementation and development of a scientific-technological consultancy service specializing in addictions" carried out from January 2013 through December 2017.[1] The CEDRO Consulting Service (SC-CEDRO) was established in 2018 based on the results of that research project.

Individuals requesting advice, guidance and psychotherapy are often referred to SC-CEDRO from UCMH and other institutions of higher education. These referrals include international students enrolled at UCMH who are either paying their own tuition or are hosted on scholarships from their governments or Cuba's. Of particular relevance in this context is follow-up of international students who abuse drugs, referred to SC-CEDRO by the Student Orientation Units of their respective faculties when this abuse poses problems for students or their colleagues.

Historically, the drugs most commonly used in Cuba have been tobacco and alcohol,[2] but the last decade has seen an overall

\section{IMPORTANCE}

The results of this study may be useful in developing preventive and therapeutic strategies in emergency situations applicable to persons with substance use disorders or addictions.
We found that patients' ability to cope successfully with challenges presented by COVID-19 were influenced by: 1) the individual's own methods for maintaining self-control (commitment to studies, projects, and work with therapists) that aided them in their goals concerning abstinence; 2) difficulties faced in addressing specific events and situations (doubts, uncertainties, disagreements, isolation and time use); 3 ) perpetuation and revivification of myths related to substances and addictive activities (exacerbation of supposed benefits of tobacco, alcohol, marijuana, overuse of social networks); and 4) tendencies toward irrationality and lack of emotional control (fear, sadness, anger, constant worry and self-imposed demands).

Our findings suggest that despite the potential negative psychological impact of preventive social isolation during the COVID-19 pandemic, individual coping mechanisms developed by these patients, aiming at improved self-control, allowed most to avoid setbacks that could have affected their recovery. Nevertheless, patients faced challenges to their recovery that were compounded by difficulties in specific situations, myths related to substances and addictive activities, and tendencies toward irrationality or lack of emotional control.

KEYWORDS COVID-19, substance-related disorders, drug users, alcoholism, tobacco use disorder, psychophysiologic disorders, psychological adaptation, interview, qualitative research, psychological resilience, medical informatics, Cuba

increase in abuse of illegal drugs (marijuana, cocaine, synthetic or 'chemical' marijuana) and prescription medications (tramadol, morphine, carbamazepine).[3,4] Polydrug use, or the use of more than one substance by the same person, is common among people who abuse substances.[5]

The most frequent non-substance addictions include illicit gambling, technological addictions (video games, internet, mobile phones, online games and social networking) and somatic addictions (compulsive physical exercise, compulsive sexual activity and eating disorders).[6,7]

Preventive social distancing in response to the COVID-19 pandemic began in Cuba on March 11, 2020,[8] and was still in effect at the time of this report (June 2020).[9] Cuban restrictions during this period included the suspension of non-essential work activities, the school year, and sporadic, targeted suspension of public and private transportation. Cuban medical students joined in research related to the COVID-19 pandemic in their communities. International medical students stayed in their student residences and were given the option of voluntarily joining research teams working in nearby areas. Classes (weekly sessions) were held virtually. Only interns (students in their sixth year of medical school) continued their hospital work.[10] These restrictions resulted in drastic changes to SC-CEDRO operations, whose institutional mandate is the diagnosis, treatment and follow-up of patients referred to the service. To this end, SC-CEDRO is comprised of a multidisciplinary team of professors and researchers, including mental health specialists. 
As of March 11, 2020, all SC-CEDRO face-to-face activities were suspended.

Nevertheless, the service itself was maintained, turning to remote modes of operation that rely on information and communications technologies (ICT).[11] Telepsychology was incorporated into professional practice, which we define as the provision of psychological services through information processing by electronic means.[12]

During the pandemic, SC-CEDRO has implemented use of telephone, email and social networks (mainly WhatsApp)[13] for therapy and monitoring of individuals requesting the service. These resources are recommended during conditions in which physical distancing is essential,[12] and have been useful in mitigating negative mental health impacts.[14]

During preventive social isolation, patients undergoing treatment for addiction may cohabitate with individuals who may try to avoid stress, tension and uncertainty through social use of alcohol or other drugs. This may favor an increase in consumption or relapse in patients faced with the challenge of organizing their daily lives in a context of pervasive stress and worry.[15]

WHO and $\mathrm{PAHO}$ have urged people not to adopt inappropriate response strategies to the pandemic, such as use of tobacco, alcohol or other drugs, since these can damage mental and physical well-being in the long term. Instead, they recommend people adopt strategies they had previously found helpful in managing stress and empowering them in the face of adverse situations.[16]

Current literature suggests that in crises caused by psychological emergencies, interventions should pay close attention to the use of psychoactive substances and other addictive behaviors.[17]

\section{INTERVENTION}

To characterize the psychological mechanisms adopted by SC-CEDRO patients in coping with the challenges posed by COVID-19 restrictions, we carried out a qualitative study using a narrative framework aimed at understanding their life experiences during the initial period of preventive social isolation (April-May 2020). As of March 2020, SC-CEDRO served a population of 83 patients who routinely attended appointments with their therapists, and with whom ICT enabled the team to maintain contact thereafter.

We selected a convenience sample of 37 individuals (Cuban and international students) who had been in treatment as of January 2020 and thus had been involved in a routine therapeutic process for at least ten weeks, and who had also made partial progress toward rehabilitation. Selection criteria included attendance at ICT therapy appointments in April and May 2020. Patients' average age was 24.7 years $(17.6 ; 26.4)$; all were students; and their main sociodemographic and clinical characteristics are specified in Table 1.

Inclusion criteria SC-CEDRO patients who continued to receive psychological care and follow-up services via ICT (telephone, email and social networks, mainly WhatsApp) who agreed to participate in the study.
Table 1: Main sociodemographic and clinical characteristics of study participants $(\mathrm{N}=\mathbf{3 7})$

\begin{tabular}{|l|r|c|}
\hline Sociodemographic characteristic & $\mathbf{n}$ & $\%$ \\
\hline Region of origin & & \\
\hline Cuban student & 14 & 37.8 \\
\hline International student (Africa) & 16 & 43.2 \\
\hline International student (Americas) & 7 & 18.9 \\
\hline Sex & & \\
\hline Male & 30 & 81.1 \\
\hline Female & 7 & 18.9 \\
\hline Marital status & & \\
\hline Single & 24 & 64.9 \\
\hline Married & 8 & 21.6 \\
\hline Divorced & 5 & 13.5 \\
\hline Current occupation & & \\
\hline University student (undergraduate) & 21 & 56.8 \\
\hline University student (postgraduate) & 5 & 13.5 \\
\hline Allied health professions student & 11 & 29.7 \\
\hline (mid-level heath technicians) & &
\end{tabular}

(mid-level health technicians)

\begin{tabular}{|r|r|r|}
\hline Type of addictive disorder & 35 & 94.6 \\
\hline Substance-related & 2 & 5.4 \\
\hline Social/activity-related & 21 & 56.8 \\
\hline Psychoactive substance and addictive social activities & & \\
\hline Alcohol & 3 & 8.1 \\
\hline Tobacco & 2 & 5.4 \\
\hline Cannabis & 8 & 21.6 \\
\hline Polydrug use & 1 & 2.7 \\
\hline Gambling & 2 & 5.4 \\
\hline Addictions to technology & & \\
\hline Consumption pattern and addictive social activities & 13 & 35.1 \\
\hline Excessive consumption (risk) & 19 & 51.4 \\
\hline Abusive use (harmful) & 2 & 5.4 \\
\hline Addictive use (dependence) & 3 & 8.1
\end{tabular}

Exclusion criteria Patients who had been diagnosed with other psychiatric disorders in addition to substance-abuse/addictionrelated disorders.

Methodology We used a semi-structured interview developed to explore study participants' experiences during preventive social isolation. We developed a 7-question guide to facilitate open dialogue on how patients were coping psychologically with the restrictions imposed by COVID-19. The guide was developed using theoretical premises obtained from case studies in the field of addiction,[18] and was subsequently evaluated and refined by experts on the subject selected from UCMH faculty in the master's degree program on substance abuse treatment and prevention. Five specialists with recognized expertise on addictive disorders participated in the survey design, all of whom were full professors and PhDs with more than ten years' practice, teaching and research linked to addition issues. Questionnaire topics covered three fundamental areas: 1) behaviors relevant to recovery (time management, therapeutic adherence and addictive temptations); 2) psychological manifestations related to emotional experiences, understanding of the indicated measures and behavior in critical situations; and 3) efficacy in developing personal goals and coping mechanisms (Table 2). 
We described the psychological coping mechanisms of these participants during the COVID-19 social isolation period, a situation that called for cognitive and behavioral adaptations in response to challenges that may have exceeded each individual's available resources.[5] Emphasis was placed on individual goals and coping strategies that played a role in preventing or facilitating setbacks or relapses.

Data collection Data were obtained through an interview conducted in Spanish with all patients. Since international students must be fluent in Spanish to access higher education in Cuba, it was not necessary to carry out interviews in other languages. However, some students elected to write reflections in their native language, with the aim of clarifying comments made during their interviews. These reflections were taken into account during data analysis. The interviews were carried out through telepsychology, specifically video calls via WhatsApp. When a participant had difficulty accessing the internet, conventional telephone and email were utilized. The complementary use of voice, video and written communications via internet allowed patients and providers to overcome geographical or temporal barriers, and difficulties caused by limitations and time restrictions placed on transportation.[12]

In the interview, participants described their daily activities and responded to the questionnaire. Interviews were recorded, and duration varied from 21 to 45 minutes (average 34 minutes). Data collection ended when no new themes emerged, suggesting that acceptable information saturation had been reached.[19] Field notes were recorded manually and integrated into interview transcriptions and reflections, which were elaborated upon by participants; most often immediately following the semi-structured interviews, and using the same medium (WhatsApp). In general, reflections complemented question 7 of the semi-structured interview: "Do you have personal coping mechanisms that allow you to overcome difficulties without losing self-control? Please elaborate." The

\section{Table 2: Questions in the study's semi-structured interview}

Questions by section
Section 1 (time management, adherence to therapy and addictive
temptations)

1. How have you organized your life around the measures put in place to prevent the spread of COVID-19?

2. How has the suspension of face-to-face psychotherapy activities affected your recovery process?

3. How have you managed withdrawal symptoms, addictive temptations, and possible relapses and setbacks?

Section 2 (psychological manifestations-affective, cognitive and behavioral)

4. How have you regulated emotional reactions associated with risk, worry and stress?

5. How have you assessed the COVID-19 control measures implemented in your social and academic spheres?

6. How would you describe your behavior in situations resulting from preventive social isolation?

Section 3 (efficacy of personal coping mechanisms)

7. Do you have personal coping mechanisms that allow you to overcome difficulties without losing self-control? Please elaborate. collection of transcripts specific to each patient were ordered and coded by a researcher who obscured personal patient data before submitting them to the research team responsible for their analysis and interpretation.

Data analysis Researchers who did not conduct interviews analyzed the data and constructed inclusive categories, querying each other to increase reliability of results. Subsequently, we developed a thematic analysis in which illustrative quotes were identified that spoke to larger themes within study participants' experiences.[20] Throughout this process, we kept in mind the psychosocial and mental health considerations pertaining to specific circumstances produced by the COVID-19 pandemic published by WHO/PAHO[16] and by professional psychiatric organizations, both Cuban and international.[21,22]

Ethics The study was approved by the Scientific Council of UCMH's General Calixto García Faculty of Medical Sciences and endorsed by the UCMH Scientific Research Ethics Committee. Each participant received information on study objectives and guarantees as to the confidentiality of their contributions. Patients were assured that their ability to participate in treatment would not be affected if they decided against participating in the study or if they abandoned the study at any point. All participants gave written consent.[23]

Results SC-CEDRO was forced to recess in March 2020 due to the spread of SARS-CoV-2 in Cuba. At that time, patients in this study were in the midst of treatment, the continuation of which during a period of physical distancing implied therapeutic challenges, as it was not possible to verify whether the skills students had been developing were proving useful or to change therapeutic modalities if or when necessary. The psychotherapy and self-help groups in which patients were enrolled had also been suspended and patients were left without direct therapeutic support. In this context, three professionals assumed tele-consulting roles and continued to interact with 65 of 83 patients $(78.3 \%)$.

Among the 37 study participants, those who consumed alcohol (22; $59.4 \%)$ as their only drug were the most common. Alcohol is easily accessible in Cuba as it is a legal and socially accepted substance. Illicit drug users were predominant in the category of polydrug use, while smoking and social addictions were rare.

We developed a conceptual map of coping mechanisms employed by individuals with disorders related to psychoactive substance abuse or other addictions, demonstrating changes caused by implementation of preventive social distancing (Figure 1).

In this context, we identified the following factors as main influences on psychological coping strategies and their success: 1) personal methods for maintaining self-control; 2) difficulties in dealing with specific events and situations; 3) perpetuation of myths related to drugs and addictive activities; and 4) irrational tendencies or a lack of emotional control.

Personal methods for maintaining self-control Of the 37 participants, $29(78.4 \%)$ had developed methods and goals during initial face-to-face treatment that helped them in maintaining abstinence during preventive isolation and kept them from relapsing into addictive behavior. When initially received at SC-CEDRO, 
Figure 1: Conceptual model of psychological coping mechanisms used by study participants during COVID-19 social isolation

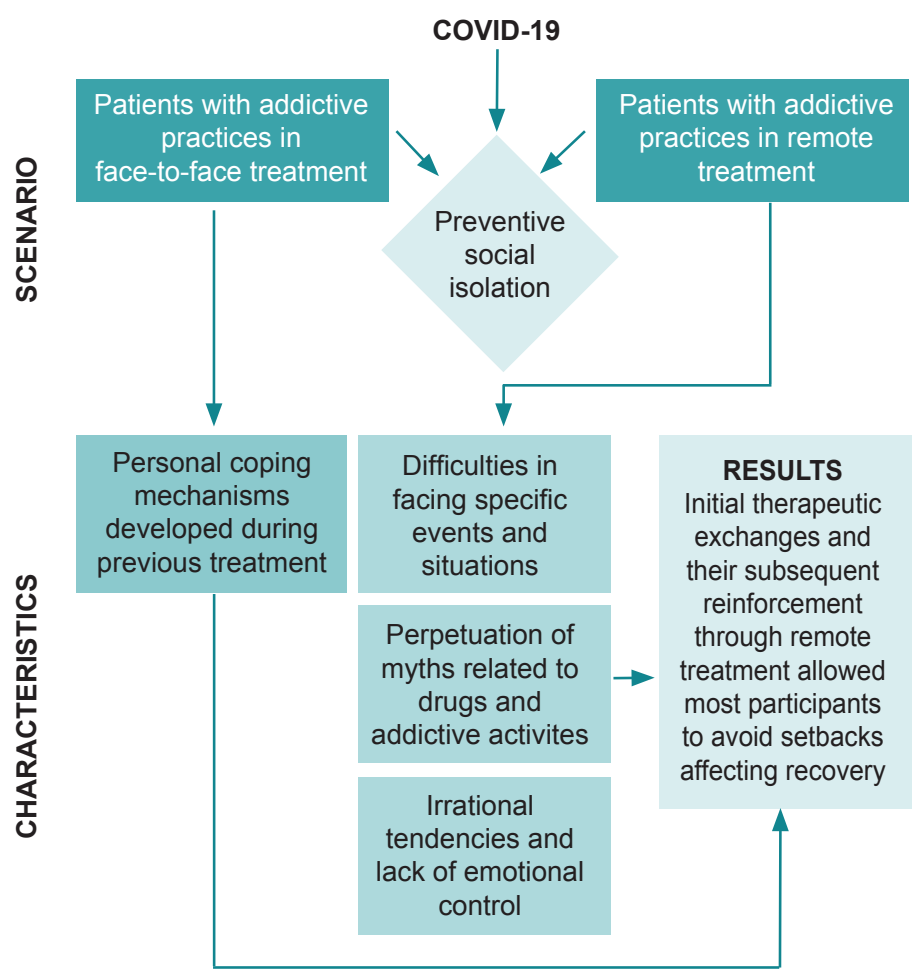

most patients were indulging in their addictions uncritically and had already faced various social and academic difficulties. The time they had been in treatment was insufficient to consolidate skills that would help guarantee abstinence and it was entirely foreseeable that relapses and setbacks would occur. However, the resources acquired in the initial stages of treatment appear to have been decisive for many patients in facilitating adequate coping with the challenges posed by the COVID-19 pandemic. The study participants indicated that they made an effort to be consistent with the profession in which they are being trained (medicine, nursing and related fields, dedicated to caring for and assisting people with health problems), consistent with their lifelong goals (usually associated with completing their university studies and being able to practice as health professionals) and respectful of commitments made with their therapists regarding abstinence and reintegration into active social life while exercising self-control and responsibility.

Despite the success of most patients in avoiding recidivism, 8 of the 37 patients $(21.6 \%)$ relapsed and re-initiated the behaviors for which they had initially began treatment. In these cases, we employed intensive tele-health assistance whenever possible and resumed face-to-face treatment as soon as circumstances allowed. In general, these eight cases were those who had not advanced as far in their treatment plans prior to the pandemic as the rest of their cohort, and those who experienced technical difficulties in accessing remote treatment.

Patient coping mechanisms were revealed in the interviews as well as the participants' written reflections. For example, one international participant stated that he had managed to control his temptation to drink alcohol by keeping in mind that he wanted to become a good doctor and parent. He wrote (edited solely for grammar):

I'm nine months sober and currently I don't feel the temptation to drink alcohol because I keep telling myself what it is I want in life and what I want to achieve. I want to be a good doctor (not a drunk doctor) and a good father (in the future). During my nine months of sobriety, there were challenges, but I defeated them, and I feel good for quitting. Now I am able to see the things I was doing while I was drunk, and my life is no longer the same.

Several participants recognized that despite their initial fear of contracting COVID-19, participating with other medical students in daily active case detection in vulnerable populations had given them a better understanding of the importance of prevention and the need to control their addictive behaviors in order to meet the demands placed on them as healthcare professionals during the pandemic and beyond. To this end, one participant said (edited solely for grammar):

Faced with this complex situation, I have been struggling to maintain the progress made in my treatment and I believe that so far I've succeeded. At first, I felt the stress building and I was surprised that the world had practically fallen apart overnight. However, l've managed to control myself, since I know that as a doctor I must be prepared to face problems like this. It has also helped me participate as a student in the daily COVID-19 case detection efforts (in the community).

Some participants said therapeutic relationships established with professionals caring for them had provided a source of inspiration, helping them control their desire to drink and avoid setbacks. Another international participant wrote:

I have not seen any change with my desire to drink during this pandemic. I am happy with the progress I have made, and I would like to thank my psychotherapist for his professional support and understanding. Many of my fellow students really need someone of your caliber to deal with whatever habit they have developed during their studies in Cuba.

These statements indicate that these participants managed to grow in the face of difficulties they encountered from changes in their personal lives as students and in the general social context. While they spent more time living at home or in the student residence with no face-to-face therapeutic support, they nevertheless were able to overcome stress-induced consumption temptations, retaining some of the progress achieved during their earlier face-to-face therapy sessions. They also adequately addressed challenges posed by the unexpected switch to remote therapy modalities.

Difficulties in dealing with specific events and situations Despite the aforementioned coping mechanisms and strategies, the greatest danger to each patient's continued recovery lay in having to face specific events and situations that exceeded their personal resources. Such difficulties were experienced by 25 participants $(67.5 \%)$, as stated in interviews. For example, some expressed doubt as to the need for some of the guidelines issued by health authorities. Although they accepted the necessity of hygienic measures and specialized care for infected patients, 
they questioned preventive social isolation and the suspension of face-to-face classes and alternative care activities such as psychotherapy and self-help groups.

Other statements reflected participant uncertainty about the efficacy of COVID-19 treatments, expressing critical views of some of the indicated therapies, opinions that relied on sources other than health authorities or healthcare providers. It was also evident that several participants were struggling with time management in their daily lives. 'Time management', for our purposes, is the particular way in which individuals organize their daily activities and implies setting aside time for study, work, family and relationships, childcare, hobbies, rest and relaxation, etc. They said that staying at home or in student residences forced them to give up their usual physical and recreational activities, and some students made little effort to resume these activities.

Some participants referred to the emergence or re-emergence of family or group disagreements. This disruption is common within families of addicts and required negotiating complications like renewed consumption or other situations that are caused or aggravated by social isolation. Likewise, other participants reported difficulties in accepting isolation from family and friends with whom they weren't living. This was a frequent comment among students whose families were either living abroad or in other Cuban provinces.

Participants also described alterations in their sleep-wake cycles generated by the changing circumstances. This was especially evident among students who did not elect to participate in research activities, for whatever reason. Additionally, students expressed worry about the inaccessibility of other sources of complementary professional help, such as psychotherapy and self-help groups (alcoholics anonymous, narcotics anonymous, etc.).

Perpetuation of myths related to drugs and addictive activities These were referred to in 19 participant interviews (51.3\% ). Such misconceptions increase the likelihood of succumbing to addictive temptations by attributing beneficial qualities to psychoactive substances and addictive behaviors - among these, greater ability to avoid adversity, generate enjoyment and strengthen sociability. The myths relayed in patient interviews referred mainly to use of tobacco, alcohol, marijuana and social networks.

Myths about tobacco. This is a drug with considerable addictive power that can lead to addiction shortly after initiating use. Tobacco's main component, nicotine, is a stimulant. The idea that tobacco is capable of generating peace or relaxation, much less that it conveys a sense of maturity or responsibility, has no basis in fact. Drugs that are smoked also produce damage to the respiratory tract, which can put users at a greater risk for developing severe forms of COVID-19.[24]

Participants expressed misguided ideas about tobacco, even if they did not habitually use the drug. For example, one participant said they had thought they might begin smoking cigarettes to decrease tension, as doing so during quarantine wouldn't result in addiction. Others said smoking during isolation would generate peace and help them relax, and some of the younger participants thought that it might make them look more mature and responsible. A few mid-level students in the allied health professions commented that since the novel coronavirus cannot survive high temperatures, smoking drugs like tobacco and marijuana might contribute to its control. These myths, gathered from participant interviews, could contribute to setbacks and addiction relapses.

Myths about alcohol. Alcohol is a depressant whose consumption in excess can generate or exacerbate problems in work and study, as well with family and other social relationships. Low alcohol concentration per drink does not lessen addictive potential, as any alcoholic beverage consumed in large quantities is capable of generating an addictive response. Alcohol's unquestionable utility in external disinfection does not mean that its consumption constitutes a preventive measure against disease.

Most of the false notions about alcohol expressed in interviews came from participants in therapy for other addictive substances or activities, who believed that alcohol is not a drug and that its consumption helps relaxation. Some participants also stated that beer and wine are not capable of generating addiction, that they are healthy lifestyle choices and useful during social isolation. Some younger students expressed that since alcohol is being used to curtail transmission by using it to disinfect hands and surfaces, then its consumption can destroy the virus in the body. These myths, if acted upon, can result in difficulty controlling alcohol misuse and may even contribute to novel addictions.

Myths about marijuana. Like any other psychoactive substance, marijuana has the potential for medicinal use, but the idea that marijuana is beneficial for health simply because it is 'natural' has no basis in fact. Like tobacco, it can result in respiratory difficulties and can contribute to severe manifestations of COVID-19.[25] Likewise, marijuana does not enhance learning abilities or the assimilation of information; on the contrary, it can have a negative effect on motivation for studying or for self-care.[26]

Some participants expressed beliefs that over-estimated the medicinal benefits of marijuana. They also described it as a 'natural product' whose use is thus beneficial to people's health. Several stated that during preventive social isolation, people in higher education may benefit from marijuana, as its use stimulates learning abilities. A Latin American participant argued that the use of natural medicines containing marijuana is a common practice in his country and that it is beneficial for relieving tension and anxiety symptoms. While we recognize cannabis' medicinal benefits, people who smoke or 'vape' (either tobacco or marijuana) are at elevated risk of severe COVID-19.[25]

Myths about social networks. Social media facilitates information sharing, but indiscriminate use can generate addiction and other problems. During disasters and emergencies such as the COVID-19 pandemic, social media can become a source of confusion and stress if all information is assumed to be factual or objective. Rumors can spread through social networks and can negatively affect people's health and well-being. Spending inordinate blocks of time on social media, including online games, can also be harmful.[27]

Themes related to the indiscriminate use of social networks and techno-addictions in general emerged during analysis. These myths were described by patients currently undergoing treatment for addiction to chemical substances who had also engaged in excessive social media use during the pandemic, often searching 
for information about COVID-19 in a compulsive manner. One participant stated that social networks are secure sources of information which only disseminate truthful news; another argued that in order to stay up-to-date regarding the pandemic, one must be aware of the rumors that are constantly generated about the SARS-CoV-2 virus. These notions can lead to indiscriminate acceptance of all manner of unsubstantiated claims made in social media, and to obsessive behaviors. In the case of social media addicts, myths prevailed regarding the habitual use of social networking activities, like the idea that regular participation in online games is a non-dangerous practice that makes social isolation more acceptable.

Irrational tendencies and lack of emotional control Of the 37 participants, $16(43.2 \%)$ expressed difficulty in controlling their emotions in conditions of preventive social isolation. They added that they often engaged in compulsive behaviors. Several participants referred to higher incidences of negative emotions like fear, sadness and anger. One participant commented that in their current circumstances, fear constitutes a frequent and unpleasant emotion, which led to feelings of immobilization, anxiety, panic and insecurity. The constant concerns surrounding not only the very real possibility of getting sick, but also the possibility of infecting family and friends, caused distress and led to feelings of melancholy and depression.

Emotional dysregulation is common during rehabilitation and social integration processes, manifesting with greater intensity during critical or difficult situations. Some participants spoke of frequent and sometimes uncontrollable anger, which was sometimes linked to feelings of resentment toward others. Additionally, several participants from outside Cuba noted that they were very affected by not knowing the current situations of their relatives, which caused them serious worry, leading to a tendency towards feelings of immobilization while waiting for news. One participant expressed frustration and sadness at what was perceived as the unfair fact that reality fails to coincide with one's desires. Many students described negative emotions associated with the belief that it is unacceptable to not be competent and successful in all circumstances one happens to encounter. However, most patients navigated these difficulties without experiencing setbacks in their recovery.

\section{LESSONS LEARNED}

Narrative designs are especially useful in social and health sciences, as they encompass attempts to understand the succession of facts, situations, phenomena, processes and events involving thoughts, feelings, emotions and interactions related by the people who experienced them.[28] Participants' statements made it possible to verify that most of them had developed coping strategies for maintaining self-control, which facilitated addressing and overcoming addictive temptations. Their treatment prior to suspension of face-to-face therapy sessions contributed to these strategies, exposing and reinforcing the incongruities of consumption and other addictive practices with the process of their professional training and their lifelong goals. The above arguments and adherence to treatment, fostered in part by commitment to their therapists, facilitated consistent positive changes in many of the patients over a short time, which in turn contributed to effective psychological coping mechanisms, allowing them to face unexpected difficulties imposed by the pandemic without setbacks or relapses.

During circumstances such as social isolation, the risks of initiating, continuing or re-initiating drug use can manifest in various ways. This depends largely on substance type or specific activities and how much treatment each individual patient has already undergone.[29] This last aspect could explain how these patients were able to face the stressful circumstances experienced: that is, they were in an intermediate stage of treatment characterized by partial progress in their rehabilitation, and already possessed a foundational understanding and an appreciation of the negative impacts consumption had on their professional training, their life goals and their interactions with their psychologists.

Participants raised doubts about the need to stop academic activities and treatments not considered to be medical emergencies. Compliance with health authorities' instructions related to social isolation and distancing as well as hygiene minimizes risk of becoming ill with COVID-19. If patients trust that complying with established guidelines will result in greater probabilities of success, they are more likely to adhere to those guidelines.[30] The background literature consulted underscores that success in COVID-19 prevention and management depends on people's behavior and on changes in their usual lifestyle.[31]

The rational use of time has been proposed as a preventive measure against risky behaviors like drug and alcohol abuse, as has attempting to maintain routines as much as possible.[32] During preventive social isolation, perception of time is altered; people often have the impression that days and nights are extremely long, they tend to be more inactive, and they sleep excessively.[33] Their normal routines disrupted, participants often failed to take into account that various activities can be done at home, including individual study, preventive actions within their residential communities and other forms of individual work or collaborative telework.

Living together in limited space can generate or exacerbate disagreements among family members or cohabiting individuals. In this case, appropriate negotiations aimed at fostering an atmosphere of understanding that facilitates continued abstinence should be promoted. One guide for psychological management of confinement during the COVID-19 crisis[34] insists these steps are essential to avoid or ameliorate symptoms of acute stress, exhaustion, irritability and insomnia.

Maintaining connections with family, friends and colleagues with whom one habitually participates in social activities, psychotherapies and self-help groups,[35] and maintaining a 'normal' sleep-wake cycle (which can help patients avoid insomnia, fears or even generalized anxiety and panic attacks) [36] are both practices that can help individuals face novel challenges.

SC-CEDRO provides patients with a care regimen based on planned consultations. However, many patients also seek guidance for challenges arising from specific needs and conflicts through psychotherapy and self-help groups. Study participants referred to the potential negative impact of the suspension of these groups during this period. 
Tobacco and rum have traditionally been considered part of Cuban culture. Globally, the purported benefits of marijuana have been disseminated through media campaigns aimed at its legalization and decriminalization.[25] Study participants made reference to myths that were exacerbated during social isolation regarding tobacco, alcohol, marijuana and the indiscriminate use of social networks.

Tobacco use generally leads to addiction.[37] Adolescents often correlate smoking with 'maturity.' Cigarette smoking can cause high blood pressure and other oncological, cardiovascular and respiratory conditions, which can lead to poor disease progression in persons infected by the SARS-CoV-2 virus.[38]

Some so-called 'new myths' were identified during interviews, which erroneously confer protection against the SARS-CoV-2 virus to certain addictive drugs and practices. The false nature of these claims is especially true in the case of drugs that are smoked, like tobacco and marijuana, as COVID-19 mainly affects the respiratory system. The harmful effects of cigarette smoking include a significant reduction in defenses and a progression towards chronic obstructive pulmonary disease, both risk factors for COVID-19.[39]

Alcohol use can also increase an individual's vulnerability to COVID-19, as it is associated with negative health effects including but not limited to a weakened immune system and an increased susceptibility to pneumonia and other acute respiratory infections.[40] Irresponsible alcohol use can lead to a lack of social discipline and a lapse in preventive measures.

WHO has warned that abuse of social media can lead to an increase in anxiety and anguish,[16] which was perceived in our interviews, whether or not participants were addicted to social media. The wave of misinformation available on social networking sites has been called an 'infodemic' and is considered a pandemic parallel to COVID-19.[41] In Cuba, ample information is provided daily on COVID-19, as national and global data are published in daily Ministry of Public Health bulletins, and resources are continually updated via national media and internet. Top Cuban health authorities appear daily in media briefings that address ongoing problems generated by the COVID-19 pandemic, and government authorities provide timely public reports on decisions taken in the national pandemic working group, charged with systematic analysis of the everevolving situation.[42]

New terms have also emerged in youth slang and popular parlance: a 'video-drink' of alcohol with friends, 'online sex', or 'sexting' as a compulsive practice.[43] A very real risk is the practice of games linked to alcohol consumption, like the one known as 'Neknomination', or 'Neknominate'. This game involves ingesting a large amount of alcohol, taking a video, uploading it to social media and inviting friends or other people to meet the 'challenge.'[44] Given that patients in this study are young and most have alcohol-related disorders, the rise of such practices constitutes a latent risk.

Lack of emotional control and tendencies toward irrationality were observed in some study participants who had to adapt to different sociocultural environments, most notably living with classmates in student residences while separated from their families. Emotional disorders are common in patients struggling with addiction and are compounded by critical situations like the pandemic. Such situations constitute mental health emergencies. [45] The control of stress-generating compulsive thoughts should be exercised as a prophylactic measure, and attention diverted to rewarding aspects of an individual's personal, family and community life. SC-CEDRO teletherapy is framed around encouraging patients to plan their days well and exercise responsible coping mechanisms when faced with challenges. Psychological interventions are based on the acceptance that reality is independent of individual will, but individuals can adopt resources allowing them to effectively deal with changes in their situations.[46] This is true for both vulnerable populations and for all those affected by the COVID-19 pandemic.

Controlling negative emotions does not constitute their denial, as they are normal in these kinds of situations.[35] Breathing exercises, relaxation, meditation and other activities have been useful in managing the anxiety caused by news about the novel coronavirus.[47] Fear can be handled positively, enhancing the perception of, and allowing individuals to better recognize, risk; and even sadness can grant individuals enriched inner dialogues and deeper self-knowledge.[48] Refusing to acknowledge these emotions can result in inadequate ability to cope with adversity. Even extremely negative reactions like anger and rage can be vehicles in achieving security, confidence and a sense of firmness. The proper management of these emotions can promote individual assertiveness and help prevent uncritical subjection to outside expectations. These emotions foster young people's defensive capacities and, when accompanied by self-control, promote the development of self-confidence and self-esteem.[49] Strengthening one's self-control of emotional states and controlling one's tendencies toward irrationality are essential.[50]

The importance of this study lies in the fact that at the time it was carried out, there was no research in Cuba that considered possible effects of situations generated by COVID-19 on people with addictions. There was concern within the services that attend to these patients, since rehabilitation requires routine therapeutic monitoring for variable time periods, plus subsequent followup appointments. The health emergency posed by COVID-19 prevented these therapies from continuing as planned, which could affect therapeutic adherence and recovery. The results of this study are useful in developing corrective strategies and preventive interventions applicable to this situation and other special circumstances related to disasters or other emergencies.

The main study limitation was the application of a qualitative narrative design through telepsychology. This implied difficulties in obtaining data from visual observation and extra-verbal communication. Even after interviews were conducted, coded and interpreted by several researchers independently and then reconciled among all researchers, it was not possible to rule out alternative interpretations. Such a case would be less likely with the use of other resources or with face-to-face interviews.

This study identified the characteristics of psychological coping mechanisms present before the COVID-19 pandemic in a group of people with disorders related to psychoactive substances and other addictions. Our findings suggest that 
despite the negative effects of the pandemic, the personal goals and mechanisms for self-control developed by participants during prior therapeutic exchanges and subsequent treatment conducted through telepsychology allowed many patients to face new and unexpected difficulties without compromising their recovery. We also identified circumstances favoring potential relapse, including difficulties in addressing specific events and situations, perpetuation of myths related to drug use and other addictive activities, and a tendency toward irrationality and lack of emotional control. - 1 h

\section{REFERENCES}

1. Fabelo-Roche JR, Iglesias-Moré S. Fortalecimiento y desarrollo del Servicio Científico Tecnológico de Consultoría Especializada en Adicciones. Proyecto de Investigación Institucional. Dirección de Ciencia e Innovación Tecnológica. Facultad General Calixto García. Havana: University of Medical Sciences of Havana; 2013-2018. Spanish.

2. Bonet Gorbea M, Varona Pérez P. III Encuesta nacional de factores de riesgo y actividades preventivas de enfermedades no transmisibles. Cuba 2010-2011 [Internet]. Havana: Editorial Ciencias Médicas; 2014 [cited 2020 Apr 23]. Available at: http://www.bvs.sld.cu/libros/encues ta_nacional_riesgo/indice_p.htm. Spanish.

3. García Rosales L, Díaz Machado A, Chang de la Rosa M, García González Y. Caracterización de las intoxicaciones agudas por drogas emergentes en Cuba consultadas al CENATOX. Periodo 2011-2015. Bol Trastor Adict. 2019;4(2):4-14. Spanish.

4. Currie Maza Y. Consumo de drogas de prescripción con fines de abuso en pacientes atendidos en el Centro Comunitario de Salud Mental Cerro. 2012 [thesis]. [Havana]: University of Medical Sciences of Havana; 2013. Spanish.

5. Fabelo Roche JR, Iglesias Moré S. Prevención y atención de los trastornos adictivos. Havana: ECIMED; 2018. Spanish.

6. Rodríguez LB. Intervención educativa sobre el uso de videojuegos en adolescentes de secundaria básica en playa Baracoa [thesis]. [Havana]: University of Medical Sciences of Havana; 2018. Spanish.

7. González-Menéndez RA. Las adicciones comportamentales: una tormenta al acecho. Rev Hosp Psiquiátrico de La Habana [Internet]. 2016 [cited 2020 May 9];13 (Suppl). Available at: https://www.medigraphic.com/pdfs/revhospsi hab/hph2016/hphs161j.pdf. Spanish.

8. Cuba confirma primeros tres casos importados de nuevo coronavirus. Radio Bayamo [Internet]. 2020 Mar 11 [cited 2020 May 16]; [about 2 p.]. Available at: http://www.radiobayamo.icrt .cu/2020/03/11/cuba-reporta-como-positivos-a -la-covid-19-tres-turistas-italianos-que-se-aloja ban-en-trinidad/. Spanish.

9. Cuba reportó siete nuevos casos de la COVID-19. Vanguardia [Internet]. 2020 Jun 30 [cited 2020 Jul 2];De Cuba:[about 4 p.]. Available at: http://www.vanguardia.cu/de-cuba/17649-cuba -reporto-siete-nuevos-casos-de-la-covid-19-el -30-de-junio. Spanish.

10. Gorry C. COVID-19 Case Detection: Cuba's Active Screening Approach. MEDICC Rev. 2020 Apr;22(2):58-63.

11. Join Task Force for the Development of Telepsychology Guidelines for Psychologists. Am Psychologist [Internet]. 2013 Dec [cited 2020 Apr 21];68(9):791-800. Available at: https:// www.apa.org/pubs/journals/features/amp -a0035001.pdf http://dx.doi.org/10.1037/a0035 001

12. Ramos Torio D, Alemán Déniz JM, Ferrer Román C, Miguel González G, Prieto Cabras V, Rico Ferrán C. Guía para la práctica de la Telepsicología [Internet]. Madrid: Spanish General Council of Psychology; 2017 Jul [cited 2020 Apr 21]. 41 p. Available at: https://doi.org/10.23923/ cop.telepsicologia.2017. Spanish.
13. De la Torre Martí M, Pardo Cebrián R. Guía para la intervención tele psicológica [Internet]. Madrid: Colegio Oficial de la Psicología de Madrid; 2017 [cited 2020 Apr 16]. 98 p. Available at: https:// www.copmadrid.org/web/publicaciones/guia -para-la-intervencion-telepsicologica. Spanish.

14. Galea S, Merchant RM, Lurie N. The mental health consequences of COVID-19 and physical distancing. The need for prevention and early intervention. JAMA Intern Med [Internet]. 2020 Apr 10 [cited 2020 May 4];180(6):817-8. DOI:10.1001/ jamainternmed.2020.1562. Available at: https:// jamanetwork.com/journals/jamainternalmedicine/ fullarticle/2764404

15. Barrales Díaz C. Atención psicológica en situaciones de emergencias y desastres. Horiz Sanitario [Internet]. 2019 Jan-Apr [cited 2020 May 9];18(1):5-6. Available at: https://dialnet.unirioja .es/descarga/articulo/6674439.pdf. Spanish.

16. Pan American Health Organization [Internet] Washington, D.C.: Pan American Health Organization; c2020. Documents. Consideraciones psicosociales y de salud mental durante el brote de COVID-19; 2020 Mar 18 [cited 2020 Apr 25]. 7 p. Spanish.

17. National Health Commission of China. [Principles of the emergency psychological crisis interventions for the new coronavirus pneumonia] [Internet]. Beijing: National Health Commission of China; 2020 [cited 2020 May 3]. Available at: http://www.nhc.gov.cn/jkj/s3577/202001/6adc08 b966594253b2b791be5c3b9467. Chinese

18. Roca Perara MA. Investigación de estudio de casos, su aplicación al campo de las adicciones. In: Fabelo Roche JR, Iglesias Moré S, editors. Prevención y atención de los trastornos adictivos. Havana: ECIMED; 2018:366-73. Spanish.

19. Charmaz K. Constructing grounded theory. 2nd ed. Los Angeles: Sage Publications, Inc.; 2014.

20. Andréu Abela J. Las técnicas de análisis de contenido: una revisión actualizada [Internet]. Granada: University of Granada (ES); 2018 [cited 2020 May 9]. 34 p.Spanish. Available at: http://mas tor.cl/blog/wp-content/uploads/2018/02/andreu -analisis-de-contenido.-34-pags-pdf.pdf. Spanish.

21. INFOMED [Internet]. Havana: Ministry of Public Health (CU); c2020. Temas de Salud. Psicología, bienestar y salud. Estrategia para el apoyo psicológico a la población y grupos de riesgo. Havana: Ministry of Public Health (CU); 2020 Mar 20 [cited 2020 May 9]; [about 6 p.]. Available at: https://temas .sld.cu/psicobienestarsalud/2020/03/20/ declaracion-conjunta-del-grupo-nacional-de -psicologia-y-la-sociedad-cubana-de-psicologia -de-la-salud/. Spanish.

22. Larroy $C$, Estupiñán $F$, Fernández-Arias I, Hervás Carmen G, Gómez M, Crespo M, et al. Guía para el abordaje no presencial de las consecuencias psicológicas del brote epidémico de COVID-19 en la población general [Internet]. Madrid: Universidad Complutense de Madrid; 2020 Mar 31 [cited 2020 May 4]. Available at: https://www .copmadrid.org/web/comunicacion/noticias/1484/ guia-el-abordaje-no-presencial-las-consecuen cias-psicologicas-brote-epidemico-covid19-la -poblacion-general. Spanish.

23. Fabelo-Roche JR. Afrontamiento psicológico a la COVID-19 a las personas que consumen sustancias psicoactivas o presentan trastornos adictivos [Internet]. Havana: University of Medical Sciences of Havana; 2020 Jun [cited 2020 Jul 3]. 15 p. Available at: https://instituciones.sld.cu/ psicologiadelasalud/files/2020/05/11-Adicciones pdf. Spanish.

24. Declaración de la OMS: consumo de tabaco y COVID-19 [Internet] World Health Organization; 2020 May 11 [cited 2021 Jan 19]. Available at: https://www.who.int/es/news/item/11-05 -2020-who-statement-tobacco-use-and-co vid-19. Spanish.

25. Pascual Pastor F, Isorna Folgar M, Carvalho N, Carvalho F, Arias Horcajadas F. Cannabis terapéutico y COVID-19: entre el oportunismo y la infoxicación. Adicciones [Internet]. 2020 [cited 2021 Jan 15];32(3):167-72. Available at: https:// www.adicciones.es/index.php/adicciones/article/ view/1603. Spanish, English.

26. González Menéndez RA. Marihuana: beneficios vs grandes riesgos. Reflexiones sobre las tendencias legalizadoras. Rev An Acad Ciencias Cuba [Internet]. 2016 [cited 2020 Mar 23];6(2). Available at: http://www.revistaccuba.cu/index.php/ revacc/article/view/341. Spanish.

27. Adhanom Ghebreyesus T, Ng A. La desinformación frente a la medicina: hagamos frente a la «infodemia» [Internet]. Geneva: World Health Organization; 2020 Feb 13 [cited 2020 May 9]. Available at: https://www.who.int/es/news-room/ commentaries/detail/coronavirus-infodemic. Spanish.

28. Hernández Sampieri R, Fernández Collado C Baptista Lucio MP. Metodología de la Investigación Científica. 6th ed. México, D.F.: McGraw Hill Education; 2014. 600 p. Spanish.

29. Colectivo de autores. Adicciones: un grave problema en el mundo. Havana: Editorial CientíficoTécnica; 2018. Spanish.

30. Eriksson M, Lindström B. Antonovsky's sense of coherence scale and its relation with quality of life: a systematic review. J Epidemiol Community Health [Internet]. 2007 Nov [cited 2020 May 9];61(11):938-44. Available at: http://dx.doi .org/10.1136/jech.2006.056028

31. Urzúa $A$, Vera-Villarroel $P$, Caqueo-Urízar $A$ Polanco-Carrasco R. La Psicología en la prevención y manejo del COVID-19. Aportes desde la evidencia inicial. Terapia Psicol [Internet]. 2020 Apr 29 [cited 2020 Mar 23];38(1):103-18. Available at: https://teps.cl/index.php/teps/article/view/ 273. Spanish.

32. Gaceta Médica [Internet]. Madrid: Gaceta Médica; c2020. Profesión. Salud mental y Covid-19: consejos para combatir el aislamiento por la pandemia; 2020 Mar 20 [cited 2020 Apr 4]; [about 2 p.]. Available at: http://gacetamedica.com/ profesion/salud-mental-y-covid-19-consejos -para-combatir-el-aislamiento-por-la-pandemia/. Spanish.

33. Alonso Maynar M, Germer CK. Autocompasión en psicoterapia y el programa Mindful Self Compassion: ¿Hacia las terapias de 4ta generación? Rev Psicoter [Internet]. 2016 Mar [cited 2020 May 9];27(103):169-85. Available at: https:// pdfs.semanticscholar.org/7e2b/56370f1d129444 11f95a9158c8c101b53850.pdf. Spanish.

34. Psiquiatría.com [Internet]. Madrid: Psiquiatría com; c2020. Actualidad. Coronavirus. Guía para el manejo psicológico del confinamiento y la crisis del COVID-19; 2020 Apr 7 [cited 
2020 Apr 17]; [about 3 p.]. Available at: https:// psiquiatria.com/article. . $h p$ ?ar=corona-virus -covid-19\&wurl=guia-para-el-manejo-psicologi co-del-confinamiento-y-la-crisis-del-covid-19. Spanish.

35. Brooks SK, Webster RK, Smith LE, Woodland L, Wessely S, Greenberg N, et al. The psychologica impact of quarantine and how to reduce it: rapid review of the evidence. Lancet [Internet]. 2020 Mar 14 [cited 2020 Mar 23];395(10227):912-20. Available at: https://www.thelancet.com/journals/ lancet/article/PIIS0140-6736(20)30460-8/fulltext

36. Lorenzo Ruiz A, Díaz Arcaño K, Zaldívar Pérez D. La psicología como ciencia en el afrontamiento a la COVID-19: apuntes generales. An Acad Ciencias Cuba [Internet]. 2020 [cited 2020 Mar 23];10(2). Available at: http://www.revistaccuba .cu/index.php/revacc/article/view/839. Spanish.

37. Lorenzo Vázquez E. Contribución de las normativas jurídicas cubanas para el control del tabaco a la prevención del tabaquismo [thesis]. [Havana]: National School of Public Health (CU); 2017. Spanish.

38. Giralt-Herrera A, Rojas-Velázquez JM, LeivaEnríquez J. Relación entre COVID-19 e hipertensión arterial. Rev Habanera Cienc Méd [Internet]. 2020 Mar-Apr [cited 2020 May 8];19(2):e3246. Available at: http://www.revhabanera.sld.cu/ index.php/rhab/article/view/3246. Spanish

39. Wu C, Chen X, Cai Y, Xia J, Zhou X, Xu S, et al. Risk factors associated with acute respiratory distress syndrome and death in patients with Coronavirus disease 2019 pneumonia in Wuhan, China. JAMA Intern Med [Internet]. 2020 Mar 13 [cited 2020 Mar 3];180(7):934-43. Available at: https://doi.org/10.1001/jamaintern med.2020.0994. Spanish.

40. Serra Valdés MA. Infección respiratoria aguda por COVID-19: una amenaza evidente. Rev Haban Cienc Méd [Internet]. 2020 Jan-Feb [cited 2020 Mar 3];19(1):1-5. Available at: http:// www.revhabanera.sld.cu/index.php/rhab/article/ view/3171. Spanish

41. Alonso-Galbán P, Alemañy-Castilla C. Curbing misinformation and disinformation in the
COVID-19 era: a view from Cuba. MEDICC Rev [Internet]. 2020 Apr [cited 2020 May 9]; 22(2):45-6. Available at: http://mediccreview .org/curbing-misinformation-and-disinformation -in-the-covid-19-era:-a-view-from-cuba

42. Información actualizada sobre la COVID-19 en Cuba [Internet]. Havana: Ministry of Public Health (CU); 2020 [cited 2020 Dec 15] Available at: https://www.apklis.cu/application/cu.sld .COVID_19_InfoCU). Spanish.

43. Caro Mantilla MM. Adicciones tecnológicas: ¿Enfermedad o conducta adaptativa? MediSur [Internet]. 2017 Mar-Apr [cited 2018 Oct 2];15(2):251-60. Available at: http://scielo.sld. cu/scielo.php?script=sci_arttext $\&$ pid=S1727 -897X2017000200014. Spanish.

44. García González Y. Intoxicación etílica. La verdad oculta tras el Neknomination. Bol Trastor Adict. 2019;4(2):1-3. Spanish

45. Xiang $\mathrm{YT}$, Yang $\mathrm{Y}$, Li $\mathrm{W}$, Zhang $\mathrm{L}$, Zhang $\mathrm{Q}$, Cheung $\mathrm{T}$, et al. Timely mental health care for the 2019 Novel Coronavirus outbreak is urgently needed. Lancet Psychiatry [Internet]. 2020 [cited 2020 Apr 15];7(3):228-9. Available at: https://do .org/10.1016/S2215-0366(20)30046-8

46. Duan L, Zhu G. Psychological interventions for people affected by the COVID-19 epidemic. Lancet Psychiatry [Internet]. 2020 Apr [cited 2020 May 6];7(4):300-2. Available at: https://doi.org/ 10.1016/S2215-0366(20)30073-0

47. Recomendaciones de la APA para manejar la ansiedad que suscitan las noticias sobre el Coronavirus [Internet]. Madrid: Infocop; 2020 Mar 3 [cited 2020 Apr 21]. Available at: http://www.info cop.es/view_article.asp?id=8595. Spanish.

48. Ribot Reyes VC, Chang Paredes N, González Castillo AL. Efectos de la COVID-19 en la salud mental de la población. Rev Haban Ciencias Méd [Internet]. 2020 [cited 2020 Jul 3];19 (Suppl). Available at: http://www.revhabanera.sld.cu/ index.php/rhab/article/view/3307. Spanish.

49. López Angulo LM, Valladares González AM. Consejería como alternativa para elevar la autorresponsabilidad y autoeficacia ante la Covid 19 MediSur [Internet]. 2020 [cited 2020 Jul 3];18(3)
Available at: http://www.medisur.sld.cu/index .php/medisur. Spanish.

50. Laxe S, Miangolarra Page JC, Chaler J, Gil Fraguas L, Gómez A, Luna F, et al. La rehabilitación en los tiempos del COVID-19. Rehabilitación (Madr) [Internet]. 2020 Jul-Sep [cited 2020 Apr 23];54(3):149-53. Available at: https://do .org/10.1016/j.rh.2020.04.001. Spanish.

\section{THE AUTHORS}

Justo Reinaldo Fabelo-Roche (Corresponding author: fabelo@infomed.sld.cu), psychologist with a master's degree in clinical psychology and a doctorate in health sciences. Full professor and senior researcher, Center for Academic Development in Drug Addiction (CEDRO) and Medical University of Havana (UCMH), Cuba. https://orcid.org/0000-0002-5316-0951

Serguei Iglesias-Moré, nurse with master's degrees in health and clinical psychology. Associate professor and associate researcher, CEDRO and UCMH, Cuba. https://orcid .org/0000-0002-3382-428X

Ana María Gómez-García, child and adolescent psychiatrist with a master's degree in comprehensive child health. Associate professor and consultant, CEDRO and UCMH, Cuba. https://orcid.org/0001-7089-2487

Submitted: June 15, 2020

Approved for publication: March 7, 2021

Disclosures: None 